REV.ILLES I IMPERIS-12 (3g)3 27/7/09 08:02 pópina 119

\title{
TRADING ROLES. GENDER, ETHNICITY, AND THE URBAN ECONOMY IN COLONIAL POTOSI
}

Jane E. Mangan, Trading Roles. Gender, Ethnicity, and the Urban Economy in Colonial Potosi, Durham, Duke University Press, 2005, 278 pp.

En los últimos años ha habido un creciente interés por los estudios históricos sobre el trabajo femenino en los mercados de Potosí. ${ }^{1}$ En Mujeres indias y señores de la coca. Potosí y Cuzco en el siglo XVI (Madrid, 2005), la historiadora Paulina Numhauser ha destacado que la explotación minera de Potosí y el negocio de la coca, cultivada en las regiones bajas del Perú, fueron dos actividades complementarias que activaron el mercado interno del virreinato peruano en la segunda mitad del siglo XVI. Muchos de los estudios sobre el Cerro Rico se han concentrado en la mita minera, y especialmente, en los «señores de ingenios», «indios mingados» o jornaleros de mingas. Por el contrario, Numhauser ha destacado la capacidad de adaptación de las mujeres indias en el comercio de mineral de plata y coca al por menor. Se trataba de reconocer la participación de nuevos agentes económicos en el proceso de transición del Tawantinsuyu al sistema mercantil colonial. $^{2}$

Otro de los estudios que se han interesado por el comercio femenino al por menor en el contexto de la economía urbana potosina de los siglos XVI y XVII es Trading Roles. Gender, Ethnicity, and the Urban Economy in Colonial Potosi, de Jane E. Mangan. Se trata de una «historia social» basada principalmente en las actividades económicas de sus protagonistas, esencialmente mujeres, que les permitía negociar su identidad «india», «mestiza»o «criolla» a través de intercambios que trascendían el ámbito económico (p. 13). Utilizando la información recogida principalmente en fuentes de los registros notariales, actas del cabildo municipal, y escrituras públicas, la autora analiza el mercado urbano como un escenario local -la Plaza del Metal, más conocido como el Gato de las Indias- en el que dichas mujeres no eran simples víctimas del sistema colonial, sino que interactuaban con diversos agentes económicos para mejorar su posición social (p. 6).

En el primer capítulo se narran los orígenes de la economía urbana desde la funda-

1. V. Abecia Valdivieso (Mitayos de Potosí en una economía sumergida, Barcelona: Técnicos Editoriales Asociados, 1988, pp. 30) llamó la atención sobre la falta de estudios sobre el trabajo femenino en los mercados de Potosí. La única excepción es Brooke Larson, «Producción doméstica y trabajo femenino indígena en la formación de una economía mercantil colonial». Historia Boliviana, n. ${ }^{\circ}$ III/2, 1983.

2. Paulina Numhauser Bar-Magen, Mujeres indias y señores de la coca. Potosí y Cuzco en el siglo XVI, Madrid: Cátedra, 2005.

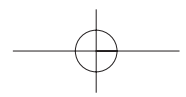


ción de Potosí en 1545 hasta finales del siglo XVI. Potosí adquirió una nueva dimensión económica en la región tras la llegada del Virrey Toledo al Perú en 1569. Hubo resistencias, pero como señala Mangan, «the fact that people took extreme measures to avoid Toleran mita regulations did not signify, however, that people avoided Potosí» (p. 43). Los indios se adaptaron rápidamente a un sistema económico mercantil basado en la minería, el comercio de productos básicos y el rescate o tráfico de plata que no había sido previamente acuñada. Mientras que los hombres orientaron sus esfuerzos hacia la industria minera, las mujeres se concentraron en la plaza del mercado, más conocido como el Gato -o kjato- de las Indias. Desde allí comerciaban con maíz, chuño, ají, cestos de coca, quínoa y productos de primera necesidad. Productos que llegaban a Potosí a través de un circuito de trajines con el fin de satisfacer la demanda del Cerro Rico.

El segundo capítulo analiza las políticas municipales orientadas a la regulación del comercio urbano potosino. Entre 1589 y 1630 su población pasó de 100.00 a 160.000 habitantes. Algunos establecimientos, como las pulperías, tambos y chicherías, experimentaron un aumento considerable. Ante esta situación, las autoridades municipales se replantearon su localización, y sobre todo, la fiscalización de sus productos. El consumo de alcohol -chicha, vino- y la venta ilícita de plata y otros productos robados a los indios amenazaba el orden y la salud pública. ${ }^{3}$ Se temía que el consumo desmesurado pusiera en peligro la estabilidad del virreinato. Algunos vecinos y empresarios utilizaron su influencia en el cabildo municipal con el fin de exigir licencias para regentar pulperías, pero como demuestran los documentos notariales consultados, muchos establecimientos operaban sin ellas. Paradójicamente, las regulaciones contrarias a la apertura de pulperías y chicherías perjudicaban los intereses económicos de algunos grupos corporativos, como los monasterios y conventos, cuyos ingresos dependían de los alquileres de dichos establecimientos. Al respecto, Mangan señala que las políticas municipales se flexibilizaron, y a partir de 1630, muchas pulperías operaron sin excesivas restricciones debido a los beneficios que generaban (p. 73-75).

En el tercer capítulo se describe la entrada de un producto indígena, la chicha, en el mercado urbano potosino y se analiza su regulación, producción y consumo local. Aunque la chicha era considerada como un producto local, los indios no dudaron en sustituirla por el trigo cuando aquella resultaba difícil de obtener. El Cabildo intervino a petición de los españoles afectados por la escasez del ingrediente básico para la fabricación del pan, legislando contra las chicheras. Los españoles pobres, sin distinción de género, se ocupaban del pan, mientras que los indios, se ocupaban de la chicha. Lo que resulta

3. Al respecto, el franciscano Bernardino de Cárdenas escribió un Memorial (1634) en el que refería como «las mujeres españolas casi las más tienen por granjería el hacer chicha, que es una bebida que se hace del maíz molido, y embriaga, aunque no con tanta fuerza como el vino. Esta chicha envía a vender, poniendo tabernillas a cada paso, pues apenas hay cuadra donde no haya dos, o tres, que estén brindando a todos los indios que pasan, y para que se aficionen más, ponen por vendedora de la chicha la más hermosa de las Indias de su servicio, la cual a trueque de que le compren la chicha, y de llevar más plata a su señora, cae en mil pecados (ô cosa digna de ser llorada con lágrimas de sangre!)» (Memorial y Relación Verdadera para el Rey Nuestro Señor y su Real Consejo de las Indias, de cosas del Reino del Perú, muy importantes a su Real servicio, y conciencia (Madrid: Imprenta de Francisco Martínez, 1634, folio 53-53v). 
significativo es que a través de estos negocios los potosinos establecieron nuevas identidades que no estaban determinadas tanto por cuestiones étnicas o raciales cuanto por cuestiones económicas.

El cuarto capítulo se centra en las actividades crediticias a pequeña escala como resultado del aumento de las actividades comerciales. Las diversas transacciones económicas que tenían lugar en Potosí, ya fuera en forma de préstamos o empeños, dependían del crédito (p. 106). Y muchas transacciones tenían lugar entre individuos del mismo grupo étnico (p. 126). Sin embargo, como apunta Mangan, no todos los grupos étnicos utilizaban el mismo tipo de sistemas crediticios. Género y etnicidad determinaba el acceso de los individuos a un tipo de crédito determinado.

En el quinto capítulo Mangan señala que las restricciones impuestas por su estado civil no fueron impedimento para ello. El matrimonio es contemplado como un instrumento para alcanzar el éxito económico, aunque, como apunta la autora, «women found places to trade whether or not they had a husband to stand behind them» (p. 140). No hay duda de que las parejas casadas tuvieron una mayor independencia económica que las mujeres solteras o las viudas, pero su iniciativa comercial era remarcable. Sin ir más lejos, algunas viudas acomodadas, ya fueran indias o españolas, alquilaban habitaciones como un medio de obtener ingresos. Otras se beneficiaron del trabajo de sus esclavas para dedicarse a la venta ambulante.

En resumen, uno de los temas recurrentes de este libro es la integración de las mujeres en el mercado local urbano así como su acceso a diferentes formas de crédito. Su objetivo no consiste en analizar la integración de Potosí en una economía mercantil a nivel regional, sino demostrar que aquella fastuosa Villa se había construido sobre la base del vitalismo económico de sus protagonistas. La constitución del mercado local no era, en modo alguno, responsabilidad del «estado colonial». Fueron los diferentes grupos étnicos, así como los españoles, los que configuraron una realidad socio-económica común. Las categorías resultantes -«mestizos», «criollos», «mulatos», etc.- no aparecen aisladas, sino que interactúan con los europeos en espacios que también son comunes. A finales del siglo XVII, la población del Cerro Rico empezó a disminuir, y con ella, sus actividades comerciales y crediticias. El asiento minero dejó de ser aquella ciudad opulenta del siglo XVI, lo que obligó a sus habitantes a adoptar nuevos alineamientos socioeconómicos en el siglo XVIII. 